\title{
Effect of Taraxerol on Testosterone Induced Prostate Cancer in Albino Wistar Rats
}

\section{Saritha $\mathbf{S}^{1}$, Prakash $\mathrm{T}^{1^{*}}$ and Ghatamaneni $\mathrm{D}^{2}$}

${ }^{1}$ Department of Pharmacology, Acharya and B.M. Reddy College of Pharmacy, Bangalore, Karnataka, India

${ }^{2}$ Department of Medical Rehabilitation, King Khalid University, Abha 62529, Saudi Arabia

*Corresponding author: Prakash T, Professor, Department of Pharmacology, Acharya and B.M. Reddy College of Pharmacy, Bangalore, Karnataka, India, Tel: +918722517795; E-mail: prakasht@acharya.ac.in

Received date: September 03, 2018; Accepted date: September 22, 2018; Published date: September 26, 2018

Copyright: $\odot 2018$ Saritha S, et al. This is an open-access article distributed under the terms of the Creative Commons Attribution License, which permits unrestricted use, distribution, and reproduction in any medium, provided the original author and source are credited.

\begin{abstract}
Prostate cancer (PC) is one of the diseases worldwide that causes cancer related deaths in men. Prostate cancer is the most common cancer in American men. The American cancer society's estimates for prostate cancer in the United States for 2017 are about 161,360 new cases of prostate cancer, About 26,730 deaths from prostate cancer. The possible effect of Taraxerol on PC has been investigated. Healthy adults male wistar albino rats were divided into five groups $(n=8)$. Group, I was served as vehicle control (arachis oil $1 \mathrm{ml} / \mathrm{kg}, \mathrm{SC}$ ), group II was served as Testosterone Depot (TD) injection (3 mg/kg, s.c in arachis oil), group III was served as standard Finasteride (5 $\mathrm{mg} / \mathrm{kg}$, p.o, and TD $3 \mathrm{mg} / \mathrm{kg}$, s.c in arachis oil), group IV was served as treated with Taraxerol (50 mg/kg p.o and TD $3 \mathrm{mg} / \mathrm{kg}$, s.c in arachis oil), group V Taraxerol (100 mg/kg p.o and TD $3 \mathrm{mg} / \mathrm{kg}$, s.c in arachis oil) for 28 days to assess preventive effect of Taraxerol. After the treatment animal was sacrificed and the prostate was removed and homogenized. Estimation of lipid peroxidation (LOP), reduced glutathione (GSH), and Glutathione peroxidase activity (GPx), Glutathione Reductase (GR), Catalase (CA), Estimation of protein levels and the histopathological changes were observed.
\end{abstract}

Keywords: Prostate cancer; Taraxerol; Testosterone depot; Lipid peroxidation; Reduced glutathione; Glutathione peroxidase; Histopathological

\section{Introduction}

Risk of prostate cancer about 1 man in 7 will be diagnosed with prostate cancer during his lifetime. Prostate cancer develops mainly in older men. About 6 cases in 10 are diagnosed in men aged 65 or older, and it is rare before age 40 . The average age at the time of diagnosis is about 66. Prostate cancer is the second leading cause of cancer death in American men. About 1 man in 39 will die of prostate cancer. Prostate cancer can be a serious disease, but most men diagnosed with prostate cancer do not die from it [1]. Studies have found that healthy natural diets can reduce prostate cancer development and inhibit metastasis. An improved lifestyle can also help reduce the incidence of cancer. In general, eating a balanced diet can efficiently minimize tumor growth and inhibit its development of advanced prostate cancer [2]. Taraxerol has inhibitory effects on AGS cell growth through inducing G(2)/M arrest and promotion of cell apoptosis [3]. Taraxerol, a triterpenoid compound, has potent anti-inflammatory effects according to a review of literature statistics suggest that Taraxerol downregulates the turn of phrase of pro-inflammatory mediators in macrophages by interfering with the activation of TAK1 and Akt, thus prevent NF- $\kappa B$ activation. Taraxerol and checkup in vitro study in prostate carcinoma. The structure was elucidated by spectroscopic techniques included Thin Layer Chromatography (TLC) and High-Performance Liquid Chromatography (HPLC), UV and Gas Chromatography-Mass Spectrometric (GC-MS). The prostate cell lines, LNCaP and PC-3 cell lines were cultured and antiproliferative effect by MTT Method, Neutral red cytotoxicity, measurement of LDH release, determinations of apoptosis by Acridine Orange (AO) and Ethidium Bromide (EB) double staining. Inhibition of protein denaturation, caspase levels by indirect ELISA and DNA fragmentation was performed [4].

\section{Materials and Methods}

The research was carried out in Acharya and B.M Reddy College of Pharmacy, Rajiv Gandhi University of Health Sciences, Bengaluru, Karnataka-560041.

\section{Collection and preparation of an extract}

The fresh bark of Annona reticulata L. were collected, washed, dried and authenticated by Dr. Ajmeera Ragan, Kakatiya University. The mature bark of collected locally were cleaned with water, shade dried and grounded into fine powder $200 \mathrm{~g}$ of $A$. reticulata $L$. the dried bark powder using Soxhlet apparatus. Each extract obtained following successive extraction was filtered using Whatman No. 1 filter paper, dried to a semisolid mass using water bath and the yield of each extract [4].

\section{Experimental animal}

Male wistar albino rats weighing between (200-250 g) Animals was procured from registered animal breeders. The animals were housed in a polypropylene cage and maintained at $24^{\circ} \mathrm{C} \pm 2^{\circ} \mathrm{C}$ less than 12 hours light/dark conditions and relative humidity of $41 \%-55 \%$ and provided with food and water ad libitum. All experiments on animals were conducted in accordance with the guidelines of CPCSEA, New Delhi, and IAEC. 


\section{Acute toxicity study}

Acute oral toxicity study of Taraxerol was carried out by adapting up and down method of CPCSEA, (OECD) guidelines No 425. The female Swiss albino mice weighing between 20-25 g were used for the study. The animal was continuously observed 12 hours to detect changes in autonomic or behavioral responses. Mortality was observed for 48 hours. All survived animals were observed for any sort of toxicity for 14 days after the drug administration according to main test criteria [5].

\section{Experimental design}

The study was planned to assess the ability of Taraxerol to cure PC due to testosterone-induced. Rats were randomly divided into five groups containing eight animals each testosterone was induced in rats a week before the start of the experiments. After the induction of PC, rats were divided into different groups. Group I: Arachis oil $1 \mathrm{ml} / \mathrm{kg}$, s.c for 28 days as vehicle control. Group II: Testosterone Depot (TD) injection $3 \mathrm{mg} / \mathrm{kg}$, s.c in arachis oil for 28 days. Group III: Finasteride 5 $\mathrm{mg} / \mathrm{kg}$, p.o, and TD $3 \mathrm{mg} / \mathrm{kg}$, s.c in arachis oil for 28 days. Group IV: Taraxerol $50 \mathrm{mg} / \mathrm{kg}$ p.o and TD $3 \mathrm{mg} / \mathrm{kg}$, s.c in arachis oil for 28 days. Group V: Taraxerol $100 \mathrm{mg} / \mathrm{kg}$ p.o and TD $3 \mathrm{mg} / \mathrm{kg}$, s.c in arachis oil for 28 days. On Day 28, the rats will be euthanized under diethyl ether anesthesia. The prostate gland was isolated and weights of right and left and total prostates was recorded and analyzed.
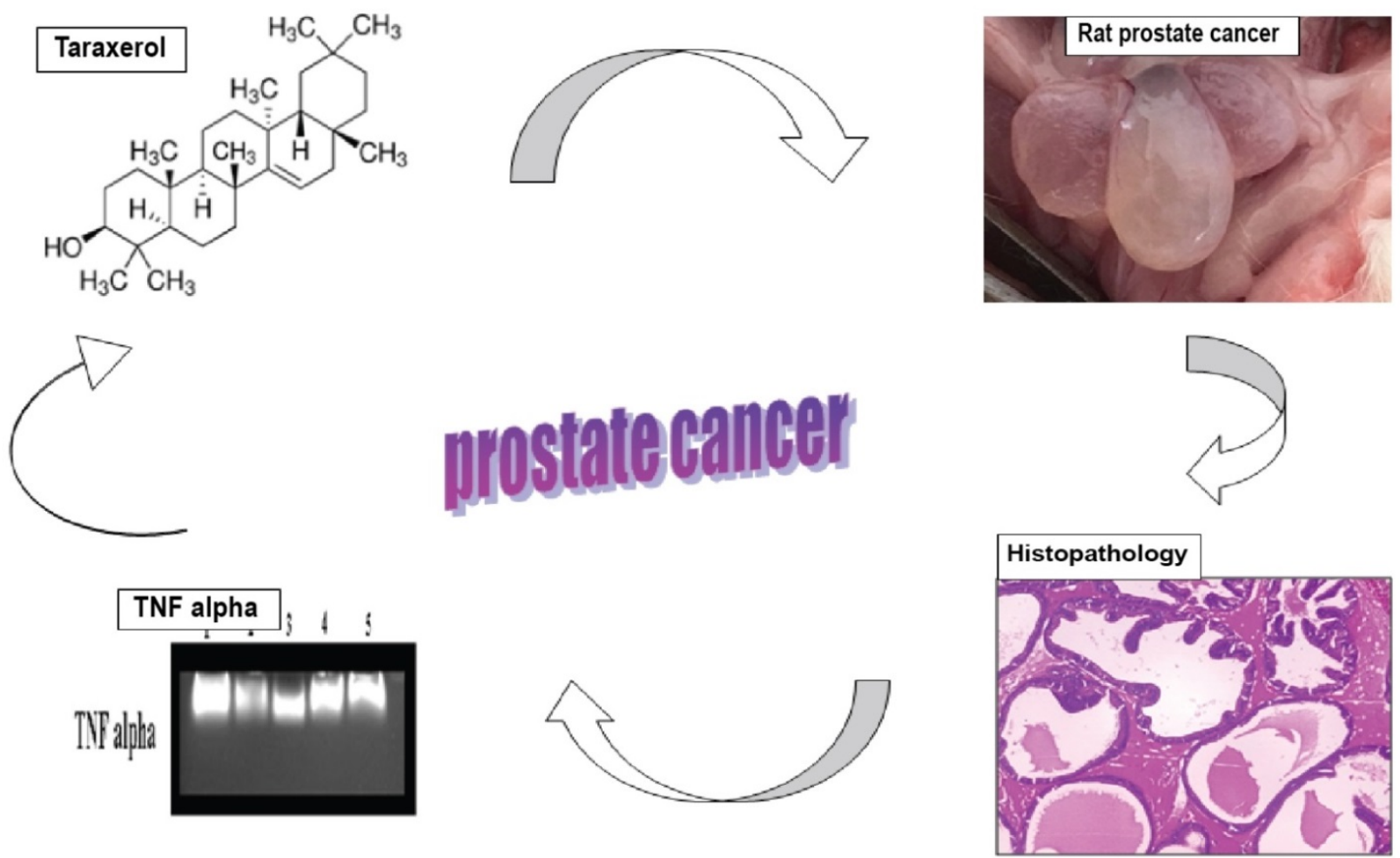

Figure 1: Graphical abstract.

\section{Biochemical parameters}

Measurement of protein: Prostate glands were dissected and homogenates were made in phosphate buffer solution $(0.01 \mathrm{M}$ sodium phosphate buffer, $\mathrm{pH} 7.4$, containing $0.14 \mathrm{M} \mathrm{NaCl}$ ) at $1 \mathrm{ml}$ volume $/ \mathrm{g}$ gland wet weight ratio of 4:1. Homogenates were centrifuged at 13,000 $\times \mathrm{g}$ for $20 \mathrm{~min}$ and supernant collected. Supernant was used as source of proteins and concentration was determined by the method of [6] using BSA as standard.

Measurement of lipid peroxidation: The assay for membrane LPO was carried out by the method of [7] with some modifications. The reaction mixture in a total volume of $3.0 \mathrm{ml}$ contains $1.0 \mathrm{ml}$ tissue homogenate, $1.0 \mathrm{ml}$ of TCA (10\%), and $1.0 \mathrm{ml}$ TBA (0.67\%). All the test tubes were placed in a boiling water bath for a period of $45 \mathrm{~min}$. The mixture was cooled and $5 \mathrm{ml}$ of $\mathrm{n}$-butanol-pyridine mixture (15:1) was added. The mixture was shaken vigorously. The tubes were shifted to an ice bath and then centrifuged at 4000 for $10 \mathrm{~min}$. the organic layer was taken and its absorbance was measured at $532 \mathrm{~nm}$. The concentration of MDA formed is expressed as $\mathrm{nM} \mathrm{MDA} / \mathrm{g}$ wet tissue. The results will be expressed as the nmol MDA formed/gram tissue by using a molar extinction coefficient of $1.56 \times 10^{5} / \mathrm{M} / \mathrm{cm}$. [8].

Measurement of reduced glutathione (GSH) levels: Reduced glutathione was estimated by the method of [9]. The protein-free supernatant was obtained by addition of an equal volume of $10 \%$ TCA and the tissue homogenate and centrifuged at $7000 \times \mathrm{g}$ for $8 \mathrm{~min}$. To 
Page 3 of 9

this $1 \mathrm{ml}$ of supernatant, $3 \mathrm{ml}$ of $0.2 \mathrm{M}$ phosphate buffer $(\mathrm{pH}$ 8) and 0.5 $\mathrm{ml}$ of $6 \mathrm{mM}$ DTNB reagent were added and vortexes. The absorbance was measured at $412 \mathrm{~nm}$ against a blank containing TCA instead of supernatant within $15 \mathrm{~min}$. The amount of glutathione is expressed as g GSH/g wet tissue.

\section{Measurement of glutathione peroxidase activity}

The assay mixture consisted of $0.2 \mathrm{ml}$ of brain homogenate $(10 \%$, $\mathrm{w} / \mathrm{v})$ and $0.2 \mathrm{ml}$ of EDTA $(0.8 \mathrm{mM}), 0.1 \mathrm{ml}$ of sodium azide $(10 \mathrm{mM})$, $0.1 \mathrm{ml}$ of $4 \mathrm{mM}$ reduced glutathione (GSH), $0.1 \mathrm{ml} \mathrm{H}_{2} \mathrm{O}_{2}(30 \mathrm{mM})$ solution, $0.4 \mathrm{ml}$ of $0.4 \mathrm{M}$ phosphate buffer ( $\mathrm{pH} 7.0$ ). Incubated at $37^{\circ} \mathrm{C}$ for $10 \mathrm{~min}$, then kept the tubes at room temperature and to this add 0.5 $\mathrm{ml}$ of $10 \%$ trichloroacetic acid (TCA) and centrifuged at $3000 \times \mathrm{g}$ for $10 \mathrm{~min}$, to this supernatant, added $0.1 \mathrm{ml}$ of $0.04 \%$ DTNB solution. Read the optical density at $420 \mathrm{~nm}$ against a blank [10].

\section{Measurement of glutathione reductase (GR) activity}

The assay consisted of $1.65 \mathrm{ml}$ of phosphate buffer (0.1 M, pH 7.6), $0.1 \mathrm{ml}$ of NADPH $(0.1 \mathrm{mM}), 0.1$ of ml EDTA $(0.5 \mathrm{mM}), 0.05 \mathrm{ml}$ of oxidized glutathione $(1 \mathrm{mM})$ and $0.1 \mathrm{ml}$ of brain homogenate $(10 \%$, $\mathrm{w} / \mathrm{v}$ ) in a total volume of $2 \mathrm{ml}$. The enzyme activity was quantitated at room temperature by measuring the disappearance of NADPH at 340 $\mathrm{nm}$ and was calculated as M NADPH oxidized/min/mg protein [11].

Measurement of catalase activity: The assay mixture consisted of 0.1 $\mathrm{ml}$ of brain homogenate $(10 \%, \mathrm{w} / \mathrm{v})$ and added $1.9 \mathrm{ml}$ of Phosphate buffer $(0.05 \mathrm{M}, \mathrm{pH}$ 7). To this mixture, $1 \mathrm{ml}$ of freshly prepared $30 \mathrm{mM}$ $\mathrm{H}_{2} \mathrm{O}_{2}$ was added and changes in absorbance were measured at $240 \mathrm{~nm}$ for $3 \mathrm{~min}$ at an interval of $30 \mathrm{sec}$. A control was prepared using $0.1 \mathrm{ml}$ of distilled water devoid of $0.1 \mathrm{ml}$ of homogenate. One unit of enzyme activity is defined as enzyme concentration required inhibiting the change in the absorbance by $50 \%$ in one min in the control sample. An activity of catalase was expressed as $\mathrm{nM}$ of $\mathrm{H}_{2} \mathrm{O}_{2}$ metabolized/min/mg protein [12].

Histopathological examinations: The prostate and testes were excised flushed with saline, fixed in $10 \%$ neutral buffered formalin for at least 24 hours and after fixation, the specimens were dehydrated in ascending grades of ethanol, cleared in benzene, and embedded in paraffin wax. Blocks were made and $5 \mu \mathrm{m}$ thick sections are cut from the prostate and testes. The paraffin embeds tissue sections were deparaffinized using xylene and ethanol. The slides are was washed with phosphate buffered saline and permeabilized with permeabilization solution $(0.1 \mathrm{M}$ citrate, $0.1 \%$ Triton $100 \mathrm{X})$. These sections were stain with hematoxylin and eosin and observed under the light microscope at $\times 40$ magnifications to investigate the histoarchitecture of prostate and testes in wistar rats [13].

\section{Results}

Different behavioral parameters and mortality were observed after $30 \mathrm{~min}$ and 48 hours and till 14 days survival of the Taraxerol dose administration. Sedation-where the animal is calm and composed without any stress. Convulsions-where there is a tremor in the tailor padding of the feet. Motor activity-in respect to increasing (or) decrease (Table 1).

\begin{tabular}{|l|l|l|l|l|l|l|}
\hline \multirow{2}{*}{$\begin{array}{l}\text { Cage } \\
\text { no. }\end{array}$} & \multirow{2}{*}{$\begin{array}{l}\text { No. of } \\
\text { mice }\end{array}$} & & \multirow{2}{*}{$\begin{array}{l}\text { Weight } \\
\text { of mice }\end{array}$} & \multicolumn{2}{|l|}{$\mathbf{1 0 0 0} \mathbf{~ m g / k g}$ dose } & \multicolumn{2}{l|}{ Route } & \multicolumn{2}{l}{$\begin{array}{l}\text { Monitored } \\
\text { parameters }\end{array}$} \\
\cline { 4 - 8 } & & & $\mathrm{mg}$ & $\mathrm{Ml}$ & & \\
\hline 1 & 1 & 20.28 & 20.28 & 0.2 & Oral & Sedation \\
\hline 2 & 1 & 20 & 20 & 0.2 & Oral & Convulsions \\
\hline 3 & 1 & 20 & 20 & 0.2 & Oral & $\begin{array}{l}\text { Motor } \\
\text { activity }\end{array}$ \\
\hline 4 & 1 & 20.28 & 20.28 & 0.2 & Oral & Mortality \\
\hline 5 & 1 & 21 & 21 & 0.2 & Oral & \\
\hline
\end{tabular}

Table 1: Acute toxicity studies.

Mortality-If any, observed after 48 hours and 72 hours. The investigation on Taraxerol induced apoptosis on the prostate cancer cell lines by increased DNA fragmentation and increased relative Caspase-3 levels [14] and correlation with the study compound is tested on animal model. PC is caused by dihydrotestosterone, a metabolite obtained from the conversion of testosterone by $5 \alpha$ reductase [4]. Consequently, inhibitors of $5 \alpha$-reductase which block production of DHT ultimately slow down the development of PC. Common inhibitors of $5 \alpha$-reductase are pharmacological agents such as Finasteride (Table 2).

\begin{tabular}{|c|c|c|c|c|c|c|c|c|c|c|c|c|c|}
\hline \multirow{3}{*}{ Cage no } & \multirow{3}{*}{$\begin{array}{l}\text { No of } \\
\text { mice }\end{array}$} & \multirow{4}{*}{$\begin{array}{l}\text { Weight of } \\
\text { mice }\end{array}$} & \multirow{3}{*}{\multicolumn{2}{|c|}{$1000 \mathrm{mg} / \mathrm{kg}$ dose }} & \multirow{4}{*}{\begin{tabular}{|l|} 
Route \\
$\min$ \\
\end{tabular}} & \multirow{2}{*}{\multicolumn{2}{|c|}{$\begin{array}{l}\text { Sedation } \\
\text { After }\end{array}$}} & \multirow{2}{*}{\multicolumn{2}{|c|}{$\begin{array}{l}\text { Convulsions } \\
\text { After }\end{array}$}} & \multirow{2}{*}{\multicolumn{2}{|c|}{$\begin{array}{l}\text { Motor activity } \\
\text { After }\end{array}$}} & \multirow{2}{*}{\multicolumn{2}{|c|}{$\begin{array}{l}\text { Mortality } \\
\text { After }\end{array}$}} \\
\hline & & & & & & & & & & & & & \\
\hline & & & & & & \multirow{2}{*}{\begin{tabular}{|l|}
30 \\
$\mathrm{~h}$ \\
\end{tabular}} & \multirow{2}{*}{\begin{tabular}{|l|}
1 \\
$\min$
\end{tabular}} & \multirow{2}{*}{$\begin{array}{l}30 \\
\mathrm{~h}\end{array}$} & \multirow{2}{*}{$\frac{1}{\min }$} & \multirow{2}{*}{\begin{tabular}{|l|}
30 \\
$\mathrm{~h}$
\end{tabular}} & \multirow{2}{*}{$\begin{array}{l}1 \\
\mathrm{~h}\end{array}$} & 48 & 72 \\
\hline & & & $\mathrm{mg}$ & $\mathrm{ml}$ & & & & & & & & $\mathrm{h}$ & \\
\hline 1 & 1 & 20.28 & 20.28 & 0.2 & oral & No & No & No & No & No & No & 0 & 0 \\
\hline 2 & 1 & 20 & 20 & 0.2 & oral & No & No & No & No & No & No & 0 & 0 \\
\hline 3 & 1 & 20 & 20 & 0.2 & oral & No & No & No & No & No & No & 0 & 0 \\
\hline 4 & 1 & 20.28 & 20.28 & 0.2 & oral & No & No & No & No & No & No & 0 & 0 \\
\hline 5 & 1 & 21 & 21 & 0.2 & oral & No & No & No & No & No & No & 0 & 0 \\
\hline
\end{tabular}

Table 2: Acute toxicity studies limit test studies. 
Page 4 of 9

However, there is strong evidence that phytochemical agents are also effective inhibitors of $5 a$-reductase and contributes to significant reduction in DHT concentrations [15]. There was a significant decrease in body weights of rats before and after testosterone treatment among groups. Administration of testosterone ( $3 \mathrm{mg} / \mathrm{kg}$, s.c., 28 days) significantly elevated the prostate weight when compared with normal controlled rats. Treatment with Taraxerol $(50 \mathrm{mg} / \mathrm{kg}$ p.o and $100 \mathrm{mg} / \mathrm{kg}$ p.o) significantly decreased prostate weights when compared to testosterone treated group $(\mathrm{P}<0.05)$. Similar effect was observed in Finasteride ( $5 \mathrm{mg} / \mathrm{kg}$ p.o) treated group, when compared with disease controlled rats (Table 3).

\begin{tabular}{|c|c|c|c|c|c|c|}
\hline Treatment Groups & Dose mg/kg,p.o & $\begin{array}{l}\text { Reduced glutathione } \\
\text { (Units/mg protein) }\end{array}$ & $\begin{array}{l}\text { CAT }(\mu \text { moles of } \mathrm{H} 2 \mathrm{O} 2 \\
\mathrm{metabolized} / \mathrm{mg} \text { protein } / \mathrm{min})\end{array}$ & $\begin{array}{l}\text { MDA (nmol/gm wet } \\
\text { tissue) }\end{array}$ & $\begin{array}{l}\text { Glutathione } \\
(\mathrm{nM} / \mathrm{g})\end{array}$ & reductase \\
\hline 1 & Normal saline & $0.0816 \pm 0.019$ & $0.158 \pm 0.001$ & $4.164 \pm 1.667$ & $0.559 \pm 0.76$ & \\
\hline ॥ & Testosterone $3 \mathrm{mgkg}$ & $1.33 \pm 0.200$ & $0.0059 \pm 0.001$ & $50.39 \pm 2.023$ & $0.579 \pm 0.199$ & \\
\hline III & Finasteride $5 \mathrm{mg} / \mathrm{kg}$ & $1.292 \pm 0.054$ & $0.0077 \pm 0.004 \mathrm{~ns}$ & $50.76 \pm 1.874 \mathrm{~ns}$ & $0.382 \pm 0.02$ & \\
\hline IV & Taraxerol $50 \mathrm{mg} / \mathrm{kg}$ & $0.4604 \pm 0.050$ ** & $0.001 \pm 0.001^{* *}$ & $30.28 \pm 1.603^{\star * *}$ & $0.488 \pm 0.056^{\star *}$ & \\
\hline V & Taraxerol 100 mg/kg & $0.3165 \pm 0.101^{* * *}$ & $0.012 \pm 0.002$ ** & $14.91 \pm 2.090^{\star * *}$ & $0.608 \pm 0.20^{\star *}$ & \\
\hline
\end{tabular}

Table 3: Effect of Taraxerol on biochemical parameters on prostate tissue. The values are expressed as Mean \pm SD ( $n=6)$. Data was analyzed by One-Way Analysis of Variance (ANOVA) followed by Dunnett's test. ${ }^{\star} \mathrm{P}<0.05$, ${ }^{\star \star} \mathrm{P}<0.01$ and ${ }^{\star \star \star} \mathrm{P}<0.001$ as compared to control group.

The percentage inhibition was found to be $85.22 \%$ by Taraxerol ( 50 $\mathrm{mg} / \mathrm{kg}$ p.o and $100 \mathrm{mg} / \mathrm{kg} \mathrm{p.o})$ and Finasteride $(5 \mathrm{mg} / \mathrm{kg})$ when compared with the normal control. Biochemical analyses showed a significant increase of the main enzymatic antioxidant defenses (MDA, GPX, GSH, GR, CAT and protein) estimated in the specific activities and elevated MDA level. Increased MDA level have been shown to be an important marker for in vivo lipid peroxidation. Oxidative stress results from a marked imbalance between free radical production and elimination by antioxidant system (Table 4 ).

\begin{tabular}{|l|l|l|l|l|l|l|l|l|}
\hline SI.no & $\begin{array}{l}\text { Tetraethoxy } \\
\text { Propane }\end{array}$ & \multicolumn{2}{l|}{ Optical Density } \\
\cline { 3 - 10 } & Trial 1 & Trial 2 & Trial 3 & Trial 4 & Trial 5 & Avg & $\mathbf{\pm}$ S.D \\
\hline 1 & 0 & 0 & 0 & 0 & 0 & 0 & 0 & 0 \\
\hline 2 & 2 & 0.142 & 0.205 & 0.149 & 0.208 & 0.143 & 0.169 & 0.033 \\
\hline 3 & 4 & 0.276 & 0.324 & 0.278 & 0.328 & 0.23 & 0.287 & 0.04 \\
\hline 4 & 6 & 0.404 & 0.441 & 0.41 & 0.451 & 0.412 & 0.423 & 0.02 \\
\hline 5 & 8 & 0.502 & 0.514 & 0.506 & 0.479 & 0.501 & 0.5 & 0.01 \\
\hline 6 & 10 & 0.649 & 0.651 & 0.635 & 0.692 & 0.674 & 0.66 & 0.02 \\
\hline
\end{tabular}

Table 4: Calibration curve for the estimation of malondialdehyde in prostate tissue.

Many clinical studies have reported strong evidence that oxidative stress is involved in the pathogenesis of prostate cancer. The oxygenfree radicals are implicated in the process of age related decline in the cognitive performance may be responsible for the development of prostate cancer or benign prostatic hyperplasia in elderly persons. Significantly increased GPX and CAT specific activities in the temporal lobe homogenates. As expected for antioxidant agents, decreased MDA level and increased the content of reduced GSH in the prostate tissue homogenates. Such regulation of oxidative stress markers by the Taraxerol may be well correlated with previous reports, where Taraxerol have antioxidant in isolated compound. Histopathology Report of Prostate (Control) Section studied shows structure of prostate consisting of glands with intervening stroma (Table 5). The glands are arranged back to back (Figure 2).

\begin{tabular}{|c|c|c|c|c|c|c|}
\hline \multirow[t]{2}{*}{ SI. No } & \multirow{2}{*}{$\begin{array}{l}\text { Reduced } \\
\text { glutathione } \\
(\mu \mathrm{g} / \mathrm{ml})\end{array}$} & \multicolumn{5}{|c|}{ Absorbance at $412 \mathrm{~nm}$} \\
\hline & & Trial 1 & Trial 2 & Trial 3 & Average & $\pm \mathrm{SD}$ \\
\hline 1 & 0 & 0 & 0 & 0 & 0 & 0 \\
\hline 2 & 20 & 0.018 & 0.016 & 0.012 & 0.01533 & 0.003 \\
\hline 3 & 40 & 0.028 & 0.026 & 0.024 & 0.02622 & 0.004 \\
\hline 4 & 60 & 0.048 & 0.05 & 0.045 & 0.04766 & 0.005 \\
\hline 5 & 80 & 0.062 & 0.064 & 0.063 & 0.06332 & 0.003 \\
\hline 6 & 100 & 0.08 & 0.074 & 0.08 & 0.07766 & 0.004 \\
\hline
\end{tabular}

Table 5: Calibration curve for the estimation of reduced glutathione. 
Citation: Saritha S, Prakash T, Ghatamaneni D (2018) Effect of Taraxerol on Testosterone Induced Prostate Cancer in Albino Wistar Rats. J Clin Exp Pharmacol 8: 252. doi:10.4172/2161-1459.1000252

Page 5 of 9

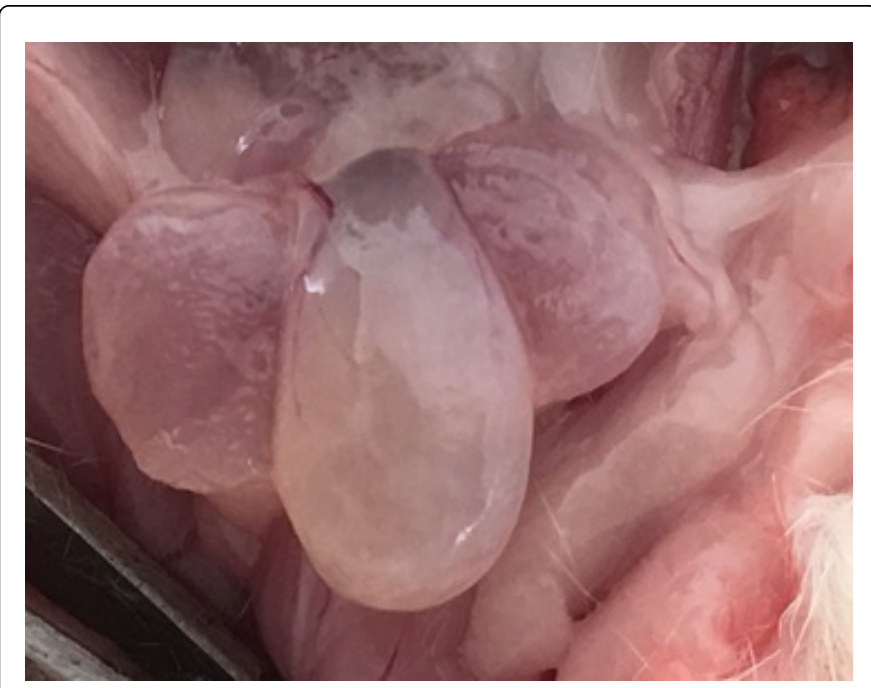

Figure 2: Testosterone induced prostate gland in rat.

The lining epithelium of these glands shows columnar epithelium having basophilic nucleus with abundant cytoplasm. Few glands show papillary projections into the lumen. Prostate (testosterone $3 \mathrm{mg} / \mathrm{kg}$ ), the lining epithelium of these glands shows columnar epithelium having vesicular nucleus with prominent nucleoli and atypia. The glands show scalloping of the prostate secretions within the lumen (Figure 3).

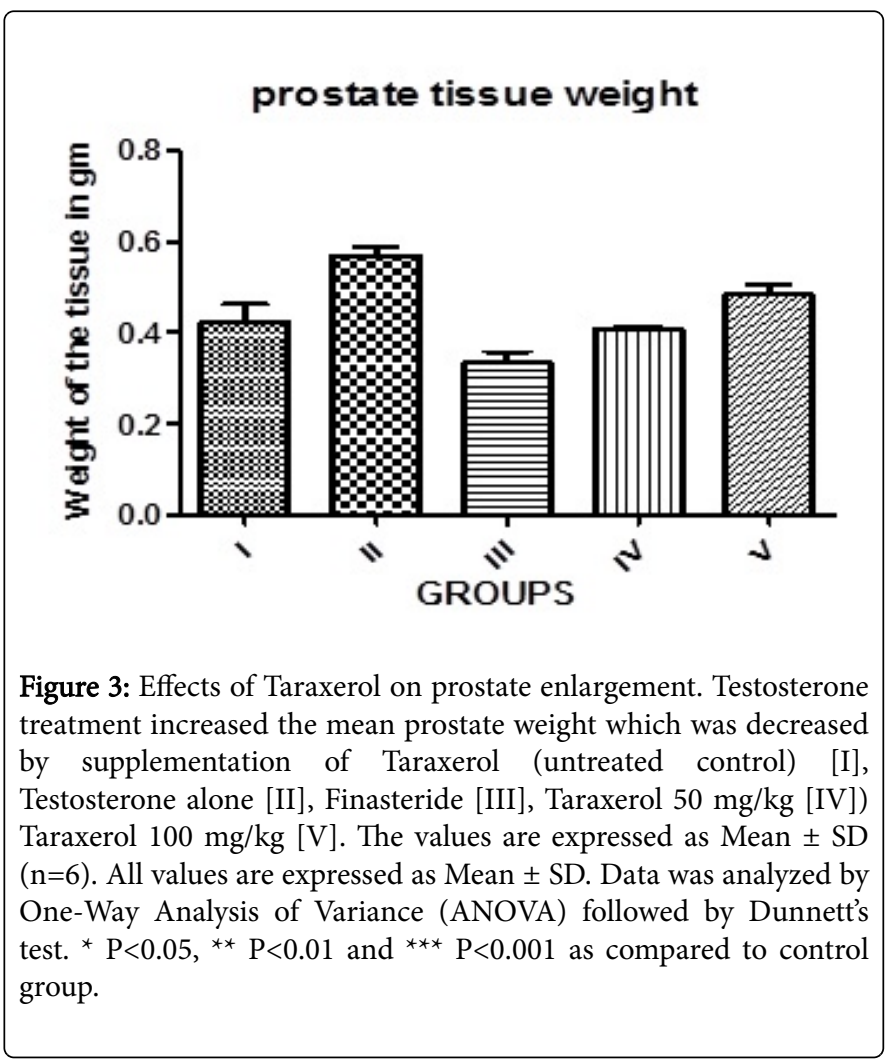

The basement membrane appears intact. Prostate (Finateride $5 \mathrm{mg} /$ $\mathrm{kg}$ ), the lining epithelium of these glands shows atrophic changes. Prostate (Taraxerol $50 \mathrm{mg} / \mathrm{kg}$ ), the lining epithelium of these glands shows columnar epithelium having basophilic nucleus with abundant cytoplasm. Few glands show papillary projections into the lumen (Figure 4).

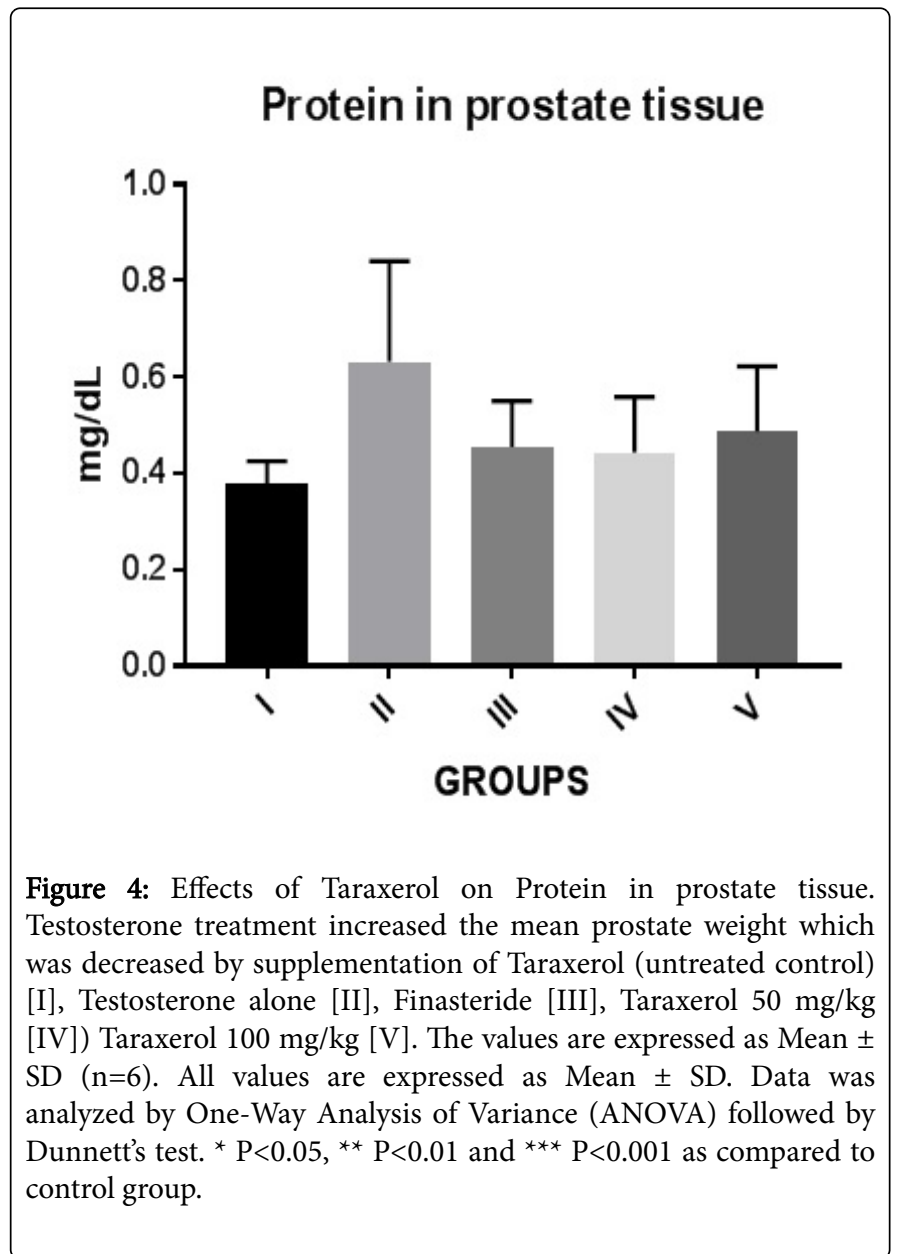

The stroma shows mild inflammatory infiltration. Prostate [Taraxerol $100 \mathrm{mg} / \mathrm{kg}$ ] the lining epithelium of these glands shows columnar epithelium having basophilic nucleus with focal hyperplastic changes. Some glands show papillary projections into the lumen. The stroma shows mild inflammatory infiltration (Figure 5).

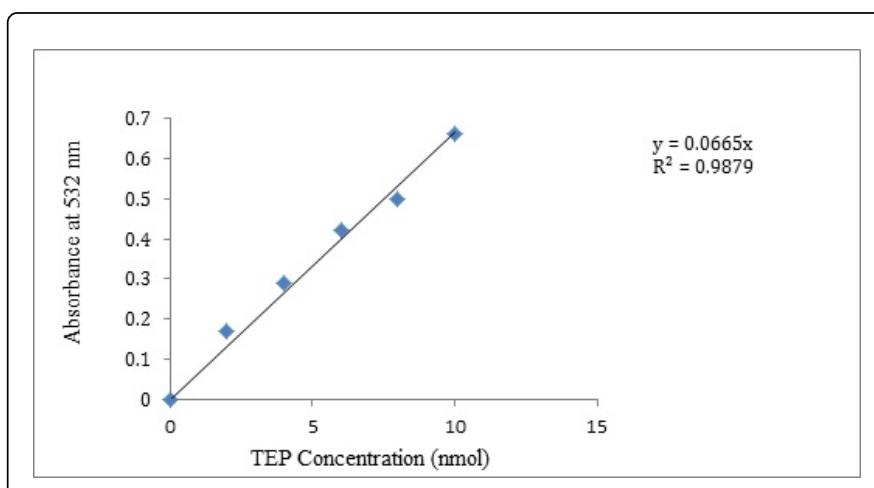

Figure 5: Calibration curve for the estimation of MDA levels in prostate tissue. 
The results obtained indicate that the Taraxerol has protective effects against the development of BPH as seen in the reduction in PSA levels, improved prostate histological patterns and increased antioxidant capacity. PSA is usually elevated in prostate disorders and is a reliable marker for prostate cancer (Figures 6-12).

\section{Lipid peroxidation}

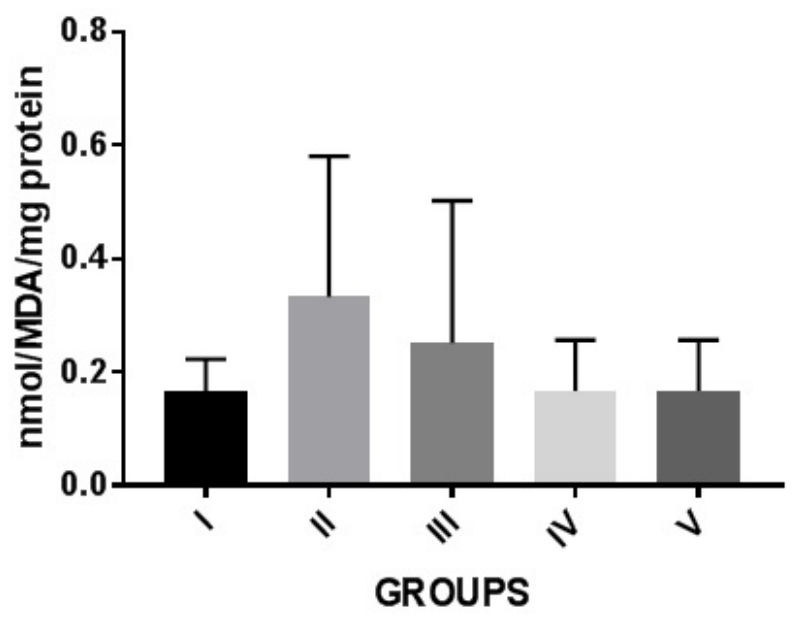

Figure 6: Biochemical analysis of testosterone induced increase of lipid peroxidation (untreated control) [I], Testosterone alone [II], Finasteride [III], Taraxerol $50 \mathrm{mg} / \mathrm{kg}$ [IV]) Taraxerol $100 \mathrm{mg} / \mathrm{kg}$ $[V]$. The values are expressed as Mean \pm SD $(n=6)$. Data was analyzed by One-Way Analysis of Variance (ANOVA) followed by Dunnett's test. ${ }^{*} \mathrm{P}<0.05,{ }^{* *} \mathrm{P}<0.01$ and ${ }^{* * *} \mathrm{P}<0.001$ as compared to control group.

\section{Discussion and Conclusion}

Different behavioral parameters and mortality were observed after $30 \mathrm{~min}$ and $48 \mathrm{~h}$ and till 14 days survival of the Taraxerol dose administration. Sedation-where the animal is calm and composed without any stress; Convulsions-where there is a tremor in the tailor padding of the feet; Motor activity-in respect to increasing (or) decrease; Mortality-if any, observed after $48 \mathrm{~h}$ and $72 \mathrm{~h}$. The investigation on Taraxerol induced apoptosis on the prostate cancer cell lines by increased DNA fragmentation and increased relative Caspase-3 levels [14] and correlation with the study compound is tested on animal model. PC is caused by dihydrotestosterone, a metabolite obtained from the conversion of testosterone by $5 \alpha$ reductase [4]. Consequently, inhibitors of $5 \alpha$-reductase which block production of DHT ultimately slow down the development of PC. Common inhibitors of 5a-reductase are pharmacological agents such as Finasteride. However, there is strong evidence that phytochemical agents are also effective inhibitors of $5 \alpha$-reductase and contributes to significant reduction in DHT concentrations [15]. There was a significant decrease in body weights of rats before and after testosterone treatment among groups.
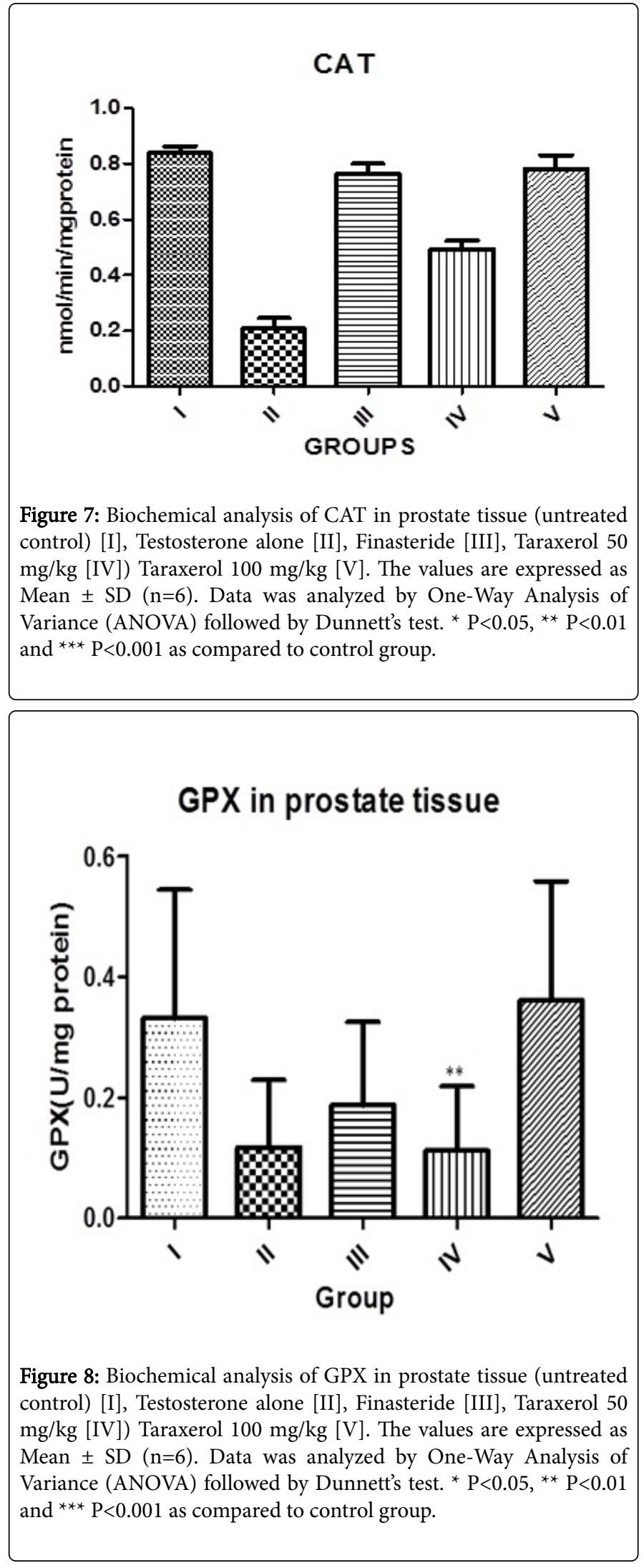


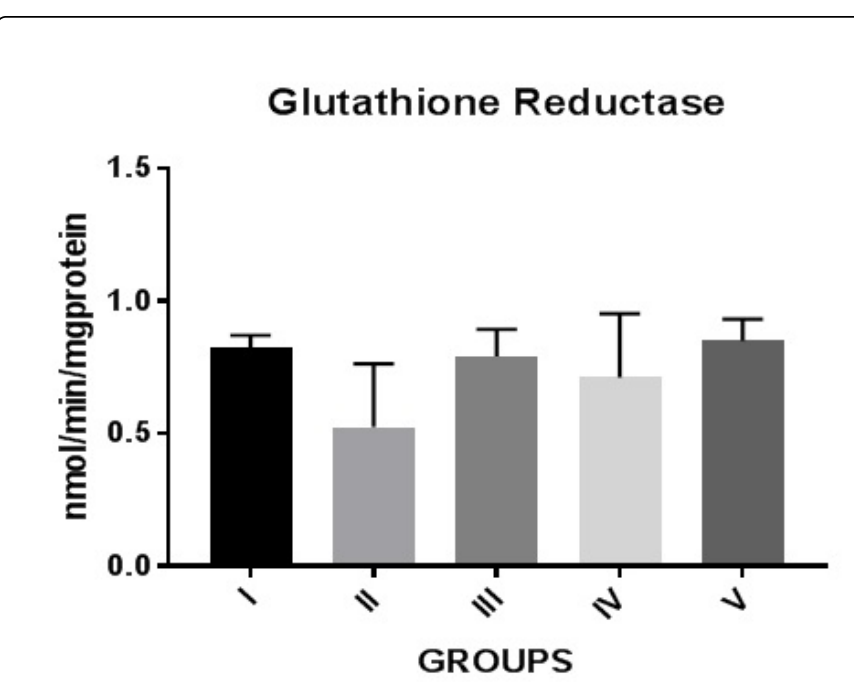

Figure 9: Biochemical analysis of Glutathione Reductase in prostate tissue (untreated control) [I], Testosterone alone [II], Finasteride [III], Taraxerol $50 \mathrm{mg} / \mathrm{kg}$ [IV], Taraxerol $100 \mathrm{mg} / \mathrm{kg}$ [V]. The values are expressed as Mean \pm SD $(n=6)$. Data was analyzed by One-Way Analysis of Variance (ANOVA) followed by Dunnett's test. ${ }^{\star} \mathrm{P}<0.05$, ${ }^{* *} \mathrm{P}<0.01$ and ${ }^{* *} \mathrm{P}<0.001$ as compared to control group.

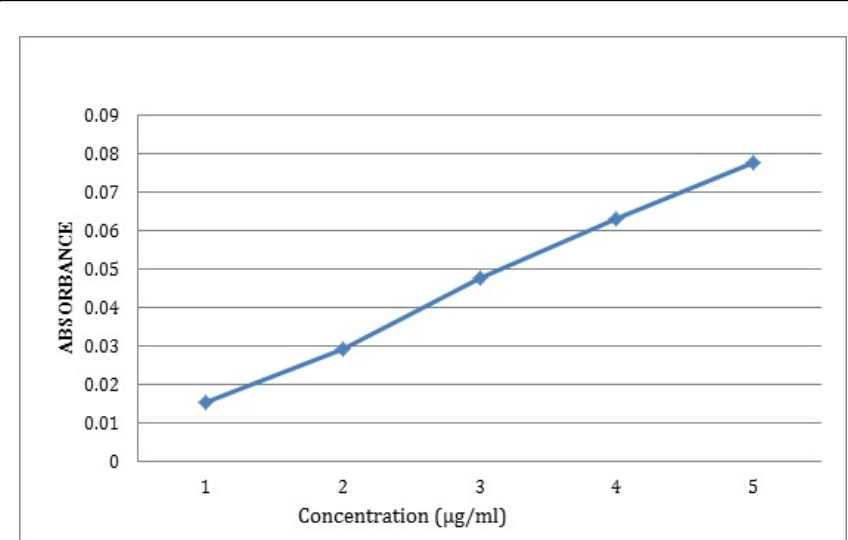

Figure 10: Calibration curve of reduced glutathione.

Administration of testosterone ( $3 \mathrm{mg} / \mathrm{kg}$, s.c., 28 days) significantly elevated the prostate weight when compared with normal controlled rats. Treatment with Taraxerol $(50 \mathrm{mg} / \mathrm{kg}$ p.o and $100 \mathrm{mg} / \mathrm{kg} \mathrm{p.o}$ ) significantly decreased prostate weights when compared to testosterone treated group $(\mathrm{P}<0.05)$. Similar effect was observed in Finasteride ( $5 \mathrm{mg} / \mathrm{kg}$ p.o) treated group, when compared with disease controlled rats. The percentage inhibition was found to be $85.22 \%$ by Taraxerol (50 mg/kg p.o and $100 \mathrm{mg} / \mathrm{kg}$ p.o) and Finasteride (5 The oxygen-free radicals are implicated in the process of age related decline in the cognitive performance may be responsible for the development of prostate cancer or benign prostatic hyperplasia in elderly persons.
Significantly increased GPX and CAT specific activities in the temporal lobe homogenates. As expected for antioxidant agents, decreased MDA level and increased the content of reduced GSH in the prostate tissue homogenates. Such regulation of oxidative stress markers by the Taraxerol may be well correlated with previous reports, where Taraxerol have antioxidant in isolated compound. Histopathology Report of Prostate (Control) Section studied shows structure of prostate consisting of glands with intervening stroma. The glands are arranged back to back (Figure 1). The lining epithelium of these glands shows columnar epithelium having basophilic nucleus with abundant cytoplasm. Few glands show papillary projections into the lumen, Prostate (Testosterone $3 \mathrm{mg} / \mathrm{kg}$ ). The lining epithelium of these glands shows columnar epithelium having vesicular nucleus with prominent nucleoli and atypia. The glands show scalloping of the prostate secretions within the lumen (Figure 2). The basement membrane appears intact, Prostate (Finateride $5 \mathrm{mg} / \mathrm{kg}$ ). The lining epithelium of these glands shows atrophic changes, Prostate (Taraxerol $50 \mathrm{mg} / \mathrm{kg}$ ). The lining epithelium of these glands shows columnar epithelium having basophilic nucleus with abundant cytoplasm. Few glands show papillary projections into the lumen.

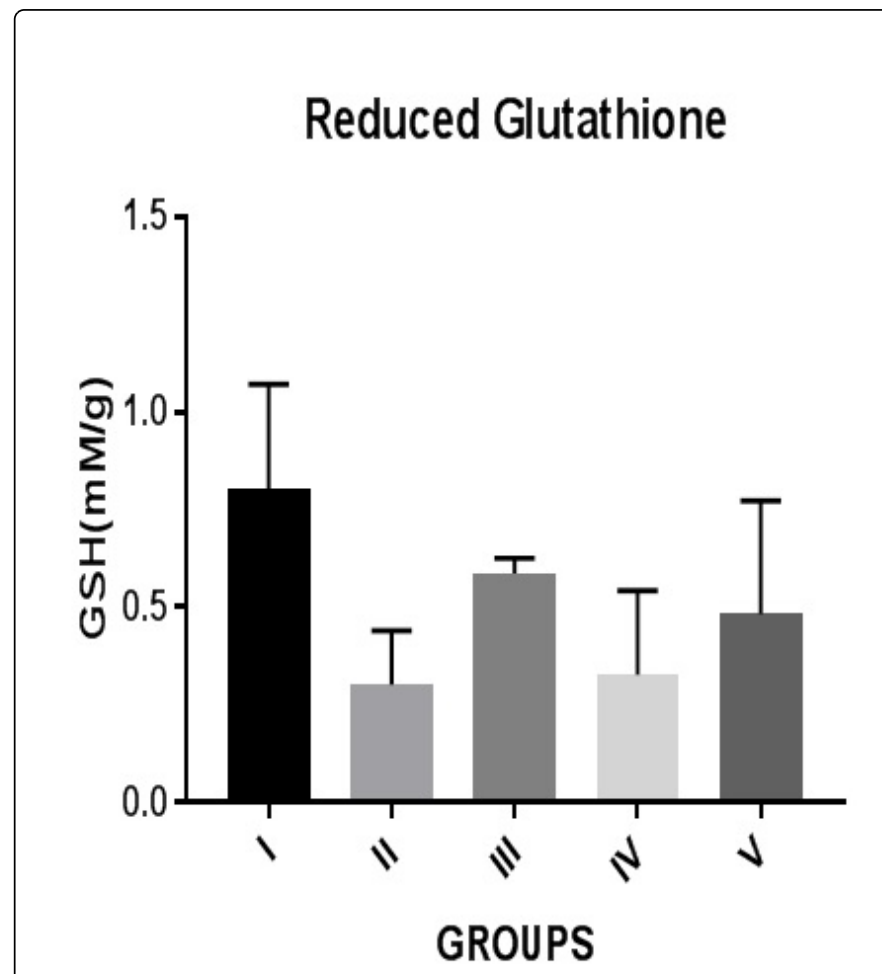

Figure 11: Biochemical analysis of reduce glutathione in prostate tissue (untreated control) [I], testosterone alone [II], Finasteride [III], Taraxerol $50 \mathrm{mg} / \mathrm{kg}$ [IV]) Taraxerol $100 \mathrm{mg} / \mathrm{kg}$ [V]. The values are expressed as Mean \pm SD $(n=6)$. Data was analyzed by One-Way Analysis of Variance (ANOVA) followed by Dunnett's test. ${ }^{\star} \mathrm{P}<0.05$, ${ }^{* *} \mathrm{P}<0.01$ and ${ }^{* * *} \mathrm{P}<0.001$ as compared to control group. 

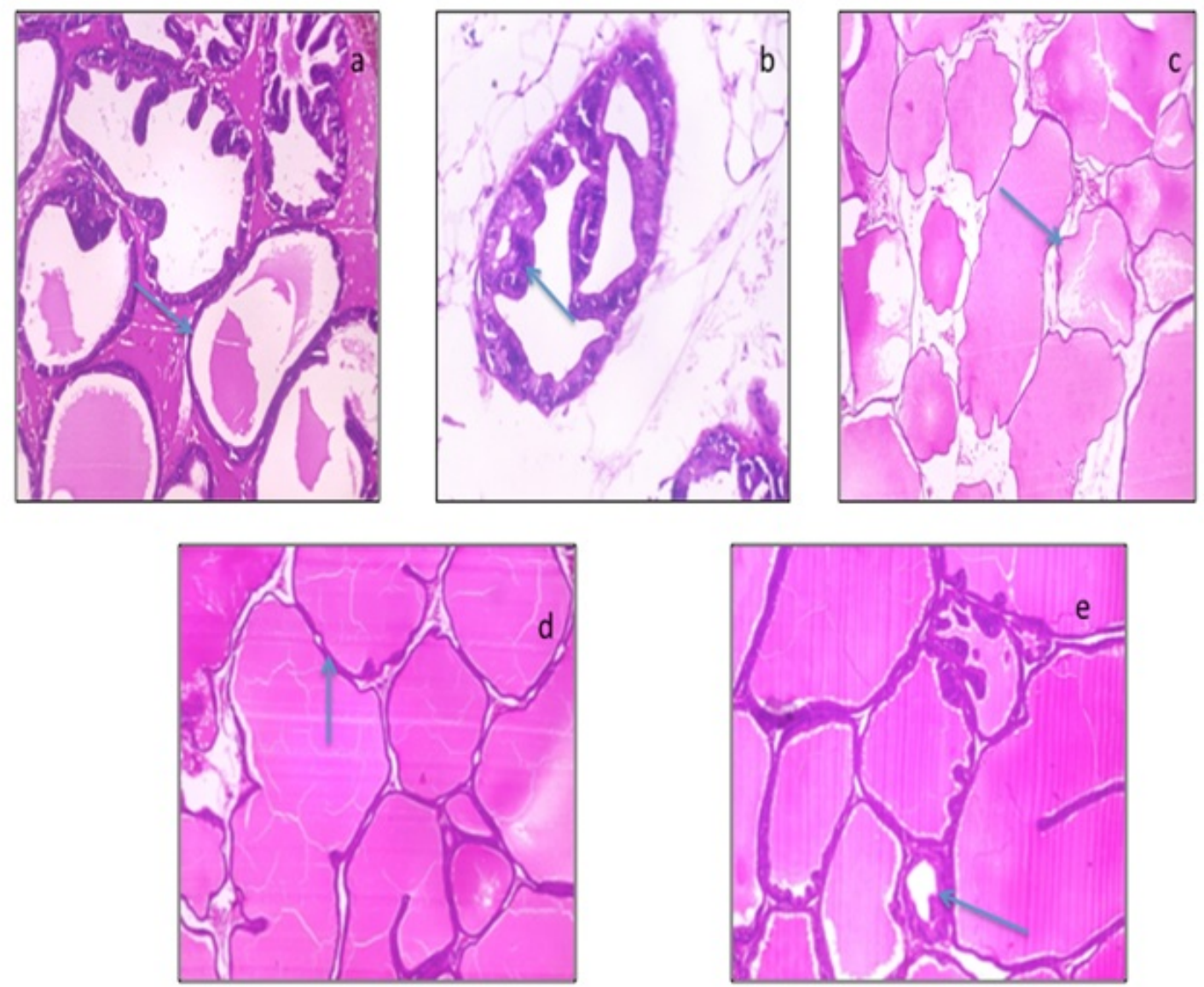

Figure 12: Effect of Taraxerol on histological slide (a) represents control Group I shows normal prostate histology. Slide (b) represents Testosterone $3 \mathrm{mg} / \mathrm{kg}$ Group II showed decreased number of scalloping of the prostate secretions within the lumen. Slide (c) represent Finateride $5 \mathrm{mg} / \mathrm{kg}$ treated Group III lining epithelium of these glands shows atrophic changes. Slide (d) represent Taraxerol $50 \mathrm{mg} / \mathrm{kg}$ treated Group IV stroma shows mild inflammatory infiltration. Slide (e) represents only Taraxerol $100 \mathrm{mg} / \mathrm{kg}$ Group V showed papillary projections.

The stroma shows mild inflammatory infiltration. Prostate (Taraxerol $100 \mathrm{mg} / \mathrm{kg}$ ) the lining epithelium of these glands shows columnar epithelium having basophilic nucleus with focal hyperplastic changes. Some glands show papillary projections into the lumen. The stroma shows mild inflammatory infiltration. The results obtained indicate that the Taraxerol has protective effects against the development of $\mathrm{BPH}$ as seen in the reduction in PSA levels, improved prostate histological patterns and increased antioxidant capacity. PSA is usually elevated in prostate disorders and is a reliable marker for prostate cancer.

\section{Acknowledgement}

The authors would like to express their gratitude to Dr. Divakar Goli, Principal and Mr. Premanath Reddy, Chairman and Mrs. Shalini
Reddy, Secretary, Acharya Institute, Bangalore, India, for providing the necessary facilities and support to carry out the research work.

\section{Conflict of Interest}

The authors declare that they do not have any conflict of interest.

\section{References}

1. http://www.cancer.org/cancer/prostatecancer/detailedguide/ prostatecancerkeystatistics.

2. Ito K (2016) Prostate cancer in Asian men. Nat Rev Urol 11: 197-212.

3. Tan B, Shi HL, Ji G, Xie JQ (2011) Effects of Taraxerol and Taraxerol acetate on cell cycle and apoptosis of human gastric epithelial cell line AGS 9: 638-42.

4. Saritha S, Prakash T (2018) Comprehensive assignments of extraction, isolation and characterization of taraxerol from bark annona reticulata $\mathrm{L}$. 
Citation: Saritha S, Prakash T, Ghatamaneni D (2018) Effect of Taraxerol on Testosterone Induced Prostate Cancer in Albino Wistar Rats. J Clin Exp Pharmacol 8: 252. doi:10.4172/2161-1459.1000252

Page 9 of 9

and chemopreventive effect on human prostate cancer cell lines (lncap and pc-3). J Carcinog Mutagen 9:313.

5. Veeresh Babu SV, Veeresh B, Patil AA, Warke YB (2010) Lauric acid and myristic acid prevent testosterone induced prostatic hyperplasia in rats. Eur J Pharmacol 626: 262-5.

6. Lowry OH, Rosebrough NJ, Farr AL, Randall RJ (1951) Protein measurement with the Folin phenol reagent. J Biol Chem 193: 265-75.

7. Wright JR, Colby HD, Miles PR (1981) Cytosolic factors which affect microsomal lipid peroxidation in lung and liver. Arch Biochem Biophys 206: 296-304.

8. Ohkawa H, Ohishi N, Yagi K (1979) Assay for lipid peroxides in animal tissues by thiobarbituric acid reaction. Anal Biochem 95: 351-8.

9. Ellman GL (1959) Tissue sulphydryl groups. Arch Biochem Biophys 82: 70-7.

10. Mohandas M, Marshall JJ, Duggin GG, Horvath JS, Tiller D (1984) Differential distribution of glutathione and glutathione related enzymes in rabbit kidney. Biochem Pharmacol 11: 1801-7.
11. Carlberg I, Mannervik B (1975) Glutathione level in rat brain. J Biol Chem 250: 4480-75.

12. Claiborne A (1985) Catalase activity in: Greenwald RA (ed) CRC handbook of methods in oxygen radical research. CRC Press, Boca Raton. $8,283-4$.

13. Lateef A, Rehman MU, Tahir M, Khan R, Khan AQ, et al. (2013) farnesol protects against intratracheally instilled cigarette smoke Extract-induced histological alterations and oxidative stress in prostate of wistar rats. Toxicol Int 20: 35-42.

14. McConnell JD, Wilson JD, George FW, Geller J, Pappas F, et al. (1992) Finasteride, an inhibitory of 5 alpha -reductase, suppresses prostatic dihydrotestosterone in men with benign prostatic hyperplasia. J Clin Endocrine Metab 74: 505-8.

15. Geavlete P, Razvan M, Bogdan G (2011) Serenoa repens extract in the treatment of benign prostatic hyperplasia. Ther Adv Urol. 3: 193-8. 